\title{
Detection of 15-bp Deletion Mutation within PLAG1 Gene and Its Effects on Growth Traits in Goats
}

\author{
Zhenyu Wei ${ }^{1}$, Ke Wang ${ }^{1}{ }^{\circledR}$, Hui Wu ${ }^{1}$, Zhen Wang ${ }^{1,2,3}$, Chuanying Pan ${ }^{1}$, Hong Chen ${ }^{1}$ and Xianyong Lan ${ }^{1, *}$ \\ 1 Shaanxi Key Laboratory of Molecular Biology for Agriculture, College of Animal Science and Technology, \\ Northwest A\&F University, Yangling 712100, China; weizhenyu0222@163.com (Z.W.); \\ lp_wangke@163.com (K.W.); wuhui582@163.com (H.W.); wangzhenid@126.com (Z.W.); \\ panyu1980@126.com (C.P.); chenhong1212@263.net (H.C.) \\ 2 Shaanxi Provincial Engineering and Technology Research Center of Cashmere Goats, Yulin University, \\ Yulin 719000, China \\ 3 Life Science Research Center, Yulin University, Yulin 719000, China \\ * Correspondence: lanxianyong79@nwsuaf.edu.cn
}

check for updates

Citation: Wei, Z.; Wang, K.; Wu, H.; Wang, Z.; Pan, C.; Chen, H.; Lan, X. Detection of 15-bp Deletion Mutation within PLAG1 Gene and Its Effects on Growth Traits in Goats. Animals 2021, 11, 2064. https://doi.org/10.3390/ ani11072064

Academic Editor: Riccardo Bozzi

Received: 28 May 2021

Accepted: 8 July 2021

Published: 10 July 2021

Publisher's Note: MDPI stays neutral with regard to jurisdictional claims in published maps and institutional affiliations.

Copyright: (c) 2021 by the authors. Licensee MDPI, Basel, Switzerland. This article is an open access article distributed under the terms and conditions of the Creative Commons Attribution (CC BY) license (https:// creativecommons.org/licenses/by/ $4.0 /)$.
Simple Summary: Goats have always served as an important domesticated livestock. PLAG1 is a major gene that affects the stature and growth of animals. Body size traits are very important for goats as it directly affects the economic characteristics of meat and cashmere production. This study showed that the 15-base pair (bp) InDel (rs637141549) can significantly affect growth traits such as body weight, height, height at hip cross, chest circumference, hip width and body index of goats through the detection of large samples $(n=1581)$ in four indigenous breeds. Accordingly, it is suggested that the deletion mutation can be used as a potential molecular marker that significantly affects goat growth traits. Moreover, the $15 \mathrm{bp}$ deletion mutation can be used as a potential molecular marker, which significantly affects the growth traits of goats and plays an important role in animal husbandry production.

Abstract: Stature and weight are important growth and development traits for animals, which also significantly affect the productivity of livestock. Polymorphic adenoma gene 1 (PLAG1) is located in the growth-related quantitative trait nucleotides (QTN), and its variation has been determined to significantly affect the body stature of bovines. This study found that novel 15-bp InDel could significantly influence important growth traits in goats. The frequencies of genotypes of the 15-bp mutation and relationship with core growth traits such as body weight, body height, height at hip cross, chest circumference, hip width and body index were explored in 1581 individuals among 4 Chinese native goat breeds. The most frequent genotypes of Shaanbei white Cashmere goat (SWCG), Inner Mongolia White Cashmere goat (IMCG) and Guanzhong Dairy goat (GZDG) were II genotypes (insertion/insertion), and the frequency of ID genotype (insertion/deletion) was found to be slightly higher than that of II genotype in Hainan Black goat (HNBG), showing that the frequency of the I allele was higher than that of the D allele. In adult goats, there were significant differences between 15 -bp variation and body weight, chest circumference and body height traits in SWCG $(p<0.05)$. Furthermore, the locus was also found to be significantly correlated with the body index of HNBG $(p=0.044)$ and hip width in GZDG $(p=0.002)$. In regard to lambs, there were significant differences in height at the hip cross of SWCG $(p=0.036)$ and hip width in IMWC $(p=0.005)$. The corresponding results suggest that the 15-bp InDel mutation of PLAG1 is associated with the regulation of important growth characteristics of both adult and lamb of goats, which may serve as efficient molecular markers for goat breeding.

Keywords: goat; growth traits; PLAG1 gene; InDel; association 


\section{Introduction}

Goats (Capra hircus) are one of oldest domesticated species and have been used globally for their meat, skins, hair, and milk. According to the Food and Agriculture Organization of the United Nations, there were more than 1.4 billion live goats worldwide in 2011 [1]. Current goat breeding programs are designed for breeding and selection of local dominant species for their excellent characteristics in meat, skin and milk by increasing the growth rate and prolificacy of goats [2,3]. Hence, it is necessary to find effective and practical measures to improve the growth characteristics of goats. Since most growth characters are quantitative with low heritability, it is difficult to improve these traits effectively through traditional phenotypic breeding [4]. However, marker-assisted selection (MAS) is helpful in rapidly establishing a better quality and high-yield population $[5,6]$. The first step of MAS is to identify some candidate genetic variations. Natural genetic variation can be divided into single nucleotide polymorphism (SNP), insertion/deletion (InDel) and copy number variant (CNV) [7]. Compared with other types of markers, InDel variants possess advantages in convenient detection and conspicuous effects $[8,9]$. Therefore, InDel has been used to explore the relationship between candidate gene variations and growth traits of different goat breeds, while MAS has been established to provide a theoretical basis for the high-quality and efficient development of the goat industry [10].

China's goat industry has been domesticated on a large scale for over a millennium. Hainan Black goat (HNBG), Inner Mongolia White Cashmere goat (IMWC), Guanzhong Dairy goat (GZDG) and Shaanbei white cashmere goats (SWCG) are all excellent indigenous breeds with different economic characteristics; however, their economic traits still need improvement. Growth traits have always been the focus of animal breeding and research, especially since many important production traits are related to body size, bringing about huge economic value in agricultural production. As a result, the identification of genetic variations in a candidate gene as well as in body shape related traits of the above four Chinese indigenous breeds is important.

The PLAG1 gene, with a length of $5.2 \mathrm{~kb}$ and four exons, is located on chromosome 14 in goats. It was originally a proto-oncogene found in pleomorphic adenomas of salivary glands [11]. Many studies on human tumors and genetically engineered mouse tumor models have established the importance and versatility of PLAG1 oncogene in tumorigenesis [12]. PLAG1 is considered to be one of the main genes in mammalian height, which has a powerful regulatory role in many important growth traits including height. According to the results of numerous genome-wide association studies and meta-analyses, PLAG1 and various adjacent gene regions have been identified as one of the loci that determine adult human stature both in Asian [13-15] and European populations [16-19]. Meanwhile, PLAG1 knock-out mice have demonstrated significant growth retardation [20]. In cattle, Karim et al. (2011) determined that the quantitative trait locus (QTL) region located between PLAG1 and CHCHD7 had a significant influence on cattle stature and weight. GWAS data has shown that several major loci, including some located in PLAG1, explain more than one third of the genetic variations of ten varieties [21]. In recent years, several studies have successively proved that genetic variations in the PLAG1 gene could regulate cattle weight, body size and other growth traits [22-24]. In pigs, PLAG1 is also considered to be a reliable candidate gene in influencing the function of limb bone length $[25,26]$. In horses, the PLAG1 gene variation has been considered to be related to body size [27]. Additionally, in a recent study, researchers have found that mutations in PLAG1 may be associated with multiple growth traits in sheep $[28,29]$. Overall, these studies have suggested that the regulatory effect of PLAG1 on growth traits may be widespread in many mammals. However, few studies exist on the polymorphism of PLAG1 in goats. Therefore, it is imperative to explore the association of the PLAG1 gene with goat growth traits. 


\section{Materials and Methods}

\subsection{Animal Sample Collection and DNA Extraction}

The experimental goat samples used in this study have been approved by the Animal Use Review Committee of Northwest Agriculture and Forestry University (NWAFU314020038). The welfare and use of laboratory animals complied with the guidelines of the Ethics Committee. A total of 1581 ear samples were gathered from healthy goats of the following Chinese native goat breeds: Hainan Black goat (HNBG, $n=212$, all adults), Guanzhong Dairy goat (GZDG, $n=91$, all adults), Inner Mongolia White Cashmere goat (IMWC, $n=452$, including 69 adults and 383 lambs) and Shaanbei white Cashmere goat (SWCG, $n=826$, including 737 adults and 89 lambs). The main growth trait statistics of the four indigenous breeds are shown in Table 1 (to ensure the accuracy of the data analysis, some phenotypic data that may be measured inaccurately were discarded or removed, which did not affect the detection of their genotype data and the analysis of population genetic parameters). The genomic DNA of all SWCG and IMCG individuals were then extracted from the ear tissues of animals raised in the Yulin goat farm in Shaanxi Province, which were all recorded growth trait data. GZDG samples were collected from the breeding base in Fuping, Shaanxi. The HNBGs were raised in Hainan Province. The growth-related data of these goats were measured and collated by veterinarians of these farms, including body weight $(\mathrm{BW}, \mathrm{kg})$, body length $(\mathrm{BL}, \mathrm{cm})$, chest circumference $(\mathrm{CC}$, $\mathrm{cm})$, body height $(\mathrm{BH}, \mathrm{cm})$, height at hip cross $(\mathrm{HAH}, \mathrm{cm})$, hip width $(\mathrm{HW}, \mathrm{cm})$, chest depth $(\mathrm{CD}, \mathrm{cm})$, chest width $(\mathrm{CW}, \mathrm{cm})$, circumference of the cannon bone $(\mathrm{CCB}, \mathrm{cm})$, body index $\left(\mathrm{BI}, \mathrm{BI}=\frac{\mathrm{CC}}{\mathrm{BL}} \times 100 \%\right)$, chest circumference index $\left(\mathrm{ChCI}, \mathrm{ChCI}=\frac{\mathrm{CC}}{\mathrm{BH}} \times 100 \%\right)$ and body length index $\left(\mathrm{BLI}, \mathrm{BLI}=\frac{\mathrm{BL}}{\mathrm{BH}} \times 100 \%\right)$ [28].

Table 1. Descriptive statistics of the main growth traits of four native breeds.

\begin{tabular}{|c|c|c|c|c|c|c|}
\hline Breeds & Growth Traits & $\begin{array}{c}\text { Effective } \\
\text { Sample Size }\end{array}$ & Mean $(\mathrm{cm})$ & $\begin{array}{c}\text { Standard } \\
\text { Error }\end{array}$ & $\underset{(\mathrm{cm})}{\operatorname{Minimum}}$ & $\underset{(\mathrm{cm})}{\operatorname{Maximum}}$ \\
\hline \multirow[t]{7}{*}{ HNBG } & $\mathrm{BH}$ & 205 & 52.80 & 0.28 & 43.20 & 63.20 \\
\hline & BL & 205 & 56.15 & 0.31 & 46.00 & 68.30 \\
\hline & CC & 205 & 72.38 & 0.46 & 54.00 & 91.00 \\
\hline & CD & 205 & 26.56 & 0.16 & 19.20 & 33.00 \\
\hline & CW & 205 & 14.91 & 0.13 & 10.80 & 21.60 \\
\hline & HW & 205 & 13.71 & 0.94 & 10.20 & 17.20 \\
\hline & $\mathrm{CCB}$ & 204 & 7.80 & 0.51 & 6.00 & 10.00 \\
\hline \multirow[t]{6}{*}{ GZDG } & $\mathrm{BH}$ & 80 & 73.53 & 0.48 & 63.00 & 83.00 \\
\hline & BL & 80 & 74.81 & 0.49 & 65.00 & 86.00 \\
\hline & HAH & 80 & 74.08 & 0.47 & 64.00 & 84.00 \\
\hline & CC & 26 & 87.50 & 0.48 & 83.00 & 92.00 \\
\hline & $\mathrm{CW}$ & 26 & 16.69 & 0.09 & 16.00 & 17.00 \\
\hline & CCB & 26 & 8.00 & 0.00 & 8.00 & 8.00 \\
\hline \multirow[t]{9}{*}{ SWCG } & BW & 649 & 48.91 & 0.61 & 15.00 & 79.00 \\
\hline & $\mathrm{BH}$ & 812 & 56.02 & 0.18 & 36.50 & 73.00 \\
\hline & BL & 634 & 66.05 & 0.24 & 46.00 & 83.00 \\
\hline & $\mathrm{HAH}$ & 811 & 58.94 & 0.17 & 23.20 & 73.00 \\
\hline & CC & 814 & 84.61 & 0.30 & 62.00 & 114.00 \\
\hline & $C D$ & 813 & 29.00 & 0.11 & 14.70 & 42.00 \\
\hline & $\mathrm{CW}$ & 814 & 19.91 & 0.13 & 11.50 & 34.00 \\
\hline & HW & 472 & 15.40 & 0.09 & 10.00 & 21.00 \\
\hline & $\mathrm{CCB}$ & 725 & 8.31 & 0.09 & 5.60 & 11.00 \\
\hline \multirow{9}{*}{ IMWC } & BW & 452 & 24.13 & 0.36 & 11.00 & 54.80 \\
\hline & $\mathrm{BH}$ & 450 & 51.44 & 0.20 & 39.50 & 65.00 \\
\hline & BL & 451 & 56.53 & 0.31 & 41.00 & 75.00 \\
\hline & $\mathrm{HAH}$ & 450 & 53.29 & 0.23 & 43.50 & 68.00 \\
\hline & CC & 450 & 69.61 & 0.37 & 55.50 & 97.00 \\
\hline & CD & 451 & 24.27 & 0.16 & 16.00 & 38.50 \\
\hline & $C W$ & 451 & 14.74 & 0.13 & 9.00 & 24.00 \\
\hline & HW & 450 & 12.97 & 0.12 & 8.50 & 53.50 \\
\hline & CCB & 450 & 8.43 & 0.03 & 7.00 & 10.00 \\
\hline
\end{tabular}

Body height, BH; body length, BL; chest width, CW; chest depth, CD; chest circumference, CC; height across the hip, HAH; rump length, RL; hip width, HW; circumference of cannon bone, CCB. 
Genomic DNA was obtained using high-salt extraction $[29,30]$. Following an analysis using an ultra-micro spectrophotometer, all DNA samples were diluted to $20 \mathrm{ng} / \mu \mathrm{L}$ of the same standard solution and stored temporarily at $4{ }^{\circ} \mathrm{C}$. In addition, 30 individual DNA samples were mixed into a genomic DNA pool for analysis via polymerase chain reaction (PCR) [30].

\subsection{Primer Design, InDel Genotyping and DNA Sequencing}

Using the Ensemble database (http:/ / www.ensembl.org/index.html, accessed on 1 October 2018) and the goat PLAG1 gene sequence (version: ENSCHIG00000000623.1), four pairs of primer for producing the 15 bp InDel locus (NC_030821.1:rs637141549, g.58752100_58752114delGAGGAGGGAGGGTTT ) in the downstream were designed (Table 2). Assays were then measured via touch-down PCR containing $8 \mathrm{ng}$ genomic DNA [10]. The PCR products were separated by $2 \%$ agarose gel electrophoresis with the aim of genotyping InDel polymorphisms in goat PLAG1. Sequencing the PCR products of different genotypes were subsequently performed in order to verify the mutations [31]. The sequencing samples were homozygous wild and mutant genotypes of SWCG. PCR products of the homozygous wild type (insertion/insertion: II) consisted of a single fragment, while that of the heterozygous mutant (insertion/deletion: ID) consisted of two fragments. Meanwhile, the PCR product of the homozygous mutant (deletion/deletion: DD) consisted of a single fragment.

Table 2. PCR primers used for detecting InDel loci of goat PLAG1 gene.

\begin{tabular}{|c|c|c|c|c|}
\hline Primer & Primer sequences (from $5^{\prime}$ to $3^{\prime}$ ) & Length & Region & $\operatorname{Tm}^{*}$ \\
\hline P1 & $\begin{array}{l}\text { F: } \\
\text { GGGGCGTCAACCTAAGAAACAT } \\
\text { R: GAAATCCGCAGTGATAGCTGG }\end{array}$ & 210 & Intron 1 & TD \\
\hline $\mathrm{P} 2$ & $\begin{array}{l}\text { F: ATGAGTTACTGGTAAGGAGA } \\
\text { R: AGAAGGCAATGGCAC }\end{array}$ & 209 & Intron 1 & TD \\
\hline P3 & $\begin{array}{l}\text { F: GAGATTCCTGTTAGAATT- } \\
\text { TATAGT } \\
\text { R: CTGAAAAGCCCCGTACT }\end{array}$ & 132 & Intron 1 & TD \\
\hline $\mathrm{P} 4$ & $\begin{array}{l}\text { F: TGAGCAACAGGGAGGGTA } \\
\text { R: TGGTGGCTACATCCAAGC }\end{array}$ & 205 & Downstream & $62{ }^{\circ} \mathrm{C}$ \\
\hline
\end{tabular}

F: forward; R: reverse; $\mathrm{Tm}^{*}$ : Temperature parameters for primer and template binding, when $50 \%$ of the primer and complementary sequence appear as double-stranded DNA molecules. TD: touch-down PCR protocol, temperatures of anneal is during $50-68^{\circ} \mathrm{C}$.

\subsection{Statistical Analysis}

The method provided by Botstein was used to calculate the genotype and allele frequencies of the InDel mutation in the goat breeds, and the genetic structure of the four native goat populations was investigated [32]. Meanwhile, the SHEsis program ( http:/ / analysis.bio-x.cn, accessed on 1 October 2018) was used to analyze the HardyWeinberg equilibrium (HWE) structure of the locus in the four native breeds [8,33]. The population genetic diversity indices were then calculated using Nei's method [34], in which the degree of homozygosity $(\mathrm{Ho})$ and heterozygosity $(\mathrm{He})(\mathrm{Ho}+\mathrm{He}=1)$ were the measures of the genetic variation of the population. Polymorphism information content (PIC) is an indicator of population polymorphism [32].

The statistical linear model: $Y_{i j}=\mu+G_{i}+e_{i j}$, where $Y_{i j}$ represents the observation of growth-related traits; $\mu$ refers to the overall average of each trait; $G_{i}$ represents the fixed effect of genotype or combined genotype; and $\mathrm{e}_{\mathrm{ij}}$ stands for random residuals $[35,36]$. The fixed effect of the genotype was the main reason for the difference in growth traits, in which the difference was considered to be significant if the $p$ value was less than 0.05 [28]. The independent sample t-test and one-way analysis of variance with post-hoc test was used to evaluate the association between the goat PLAG1 gene and main growth traits in SPSS (Version 24.0, Inc., Chicago, IL, USA). 


\section{Results}

\subsection{Detection and Genotyping of the PLAG1 Gene in Goat}

Combined with DNA sequencing and alignment analysis, one 15-bp InDel (InDel NC_030821.1:rs637141549, g.46441-46455delGAGGAGGGAGGGTTT, P4-15-bp InDel) in downstream of the PLAG1 gene was identified in all four breeds (Figure 1). Genotyping of PLAG1 gene InDel was performed by PCR-based amplification of fragment length polymorphism and three different genotypes of the locus could be obtained: homozygote insertion type (II, $205 \mathrm{bp}$ ), deletion type (DD, $190 \mathrm{bp}$ ), and heterozygote type (ID, $205 \mathrm{bp}$ and $190 \mathrm{bp}$ ). The proof results were verified by PCR products sequencing, the deletion sequence is GAGGAGGGAGGGTTT. Based on these results, the locus is consistent with the predicted InDel information of the Ensemble database.

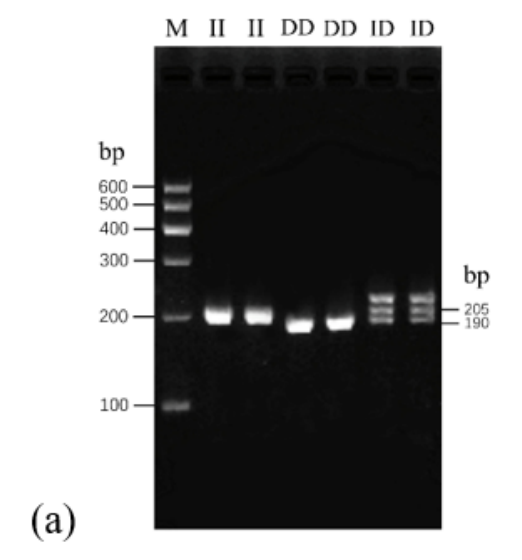

(b)

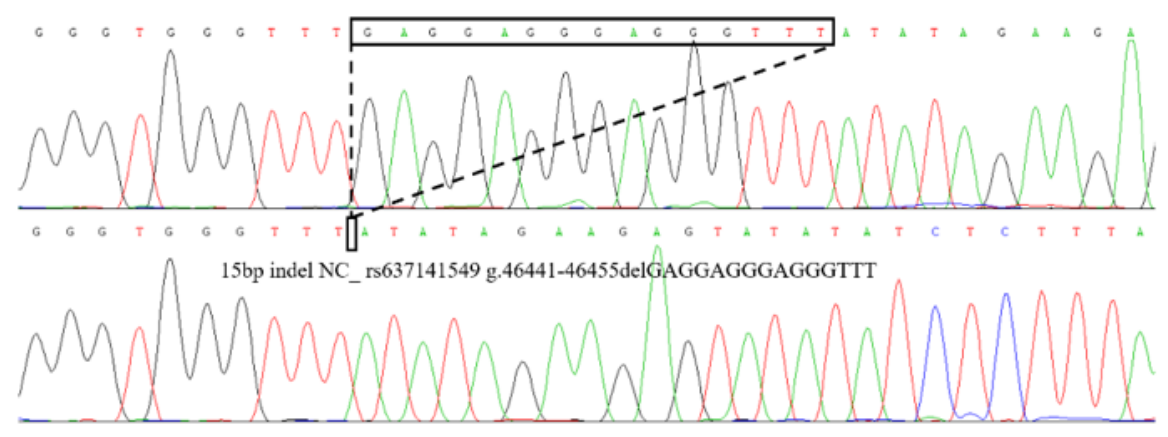

Figure 1. (a) Agarose gel electrophoresis patterns of goat PLAG1 gene P4-15-bp InDel. Maker, M. (b) Sequencing maps for the $15 \mathrm{bp}$ InDel within the goat PLAG1 gene. The sequence within the black border shows the difference in the sequence fragment.

\subsection{Population Genetic Parameter Analysis}

The genotype distribution, genotype frequencies and allele frequencies $(\mathrm{Ho}, \mathrm{He}, \mathrm{Ne}$ and PIC) of the PLAG1 genes among the four breeds goat are shown in Table 3. For P1-15bp InDel, the most frequently encountered genotypes of SWCG, IMCG and GZDG were all found to be II genotypes. However, in HNBG, the frequency of the ID genotype was slightly higher than that of the II genotype. Specifically, the frequency of the D allele was lower than that of the I allele, suggesting that I was the dominant allele. The experimental results demonstrated that the Ne of all breeds was between 1 and 2. Meanwhile, the 15-bp InDel showed intermediate polymorphism $(0.25<\mathrm{PIC}<0.5)$ in HNBG. In addition, all three varieties exhibited low polymorphism. These results indicated that the InDel mutation of goat PLAG1 contained rich genetic diversity in the analyzed population. Moreover, the $x 2$ test indicated that none of the tested populations met HWE $(p<0.05)$. Accordingly, it was clear that feeding management factors significantly affected the distribution of genotype and allele frequency.

Table 3. Genotypic, allelic frequencies, and population indexes for the15-bp InDel in four indigenous goat breeds.

\begin{tabular}{cccccccccccc}
\hline \multirow{2}{*}{ Breeds } & \multicolumn{2}{c}{ Size } & \multicolumn{3}{c}{ Genotypic Frequencies } & \multicolumn{2}{c}{ Allelic Frequencies } & \multicolumn{2}{c}{ HWE } & \multicolumn{3}{c}{ Population Parameters } \\
\cline { 2 - 11 } & N & II & ID & DD & I & D & $p$ Values & Ho & He & Ne & PIC \\
\hline SWCG & 826 & 0.805 & 0.190 & 0.005 & 0.900 & 0.100 & $p<0.05$ & 0.820 & 0.180 & 1.219 & 0.163 \\
IMWC & 452 & 0.695 & 0.281 & 0.024 & 0.835 & 0.165 & $p<0.05$ & 0.725 & 0.275 & 1.380 & 0.237 \\
HNBG & 212 & 0.439 & 0.486 & 0.075 & 0.682 & 0.318 & $p<0.05$ & 0.566 & 0.434 & 1.767 & 0.340 \\
GZDG & 91 & 0.944 & 0.056 & 0.000 & 0.973 & 0.027 & $p<0.05$ & 0.947 & 0.053 & 1.056 & 0.052 \\
\hline
\end{tabular}

SWCG, Shaanbei White Cashmere goat; IMWC: Inner Mongolia White Cashmere goat; HNBG: Hainan Black goat; GZDG: Guanzhong Dairy goat; HWE, Hardy-Weinberg equilibrium; Ho, observed homozygosity; He, heterozygosity; Ne, effective allele numbers; PIC, Polymorphism information content. 


\subsection{Relationship between PLAG1 InDel and Growth-Related Traits}

Different genotypes of $15 \mathrm{bp}$ - Indel mutations were found to be significantly related to the core growth characteristics in goat breeds, with body weight, body height, height at hip cross, chest circumference, hip width and body index of four superior varieties $(p<0.05$ or $p<0.01$ ) (Tables 4 and 5). Among them, extremely significant differences were present in the body weight traits in adult SWCG $(p=0.0006)$. Moreover, significant differences in body height of adult SWCG ( $p=0.022)$ existed, while there were significant differences in height at hip cross of lamb SWCG $(p=0.036)$. Additionally, different genotypes of this variation locus were noted to be significantly correlated with the chest circumference of SWCG and body index of HNBG ( $p=0.044)$. Interestingly, the II genotype was found to be both a dominant and superior genotype, having a better phenotype than the ID genotype, regardless of breed and age. However, in the other two breeds, the ID genotype had an extremely significant difference in hip width in adult GZDG $(p=0.002)$ and lamb IMWC $(p=0.005)$.

Table 4. Association of the 15-bp InDel and growth traits of four adult indigenous goat breeds (mean $\pm \mathrm{SE}$ ).

\begin{tabular}{|c|c|c|c|c|c|}
\hline \multirow{2}{*}{ Breeds } & \multirow{2}{*}{ Growth Traits } & \multicolumn{3}{|c|}{ Genotypes } & \multirow{2}{*}{$p$ Value } \\
\hline & & II & ID & DD & \\
\hline \multirow{9}{*}{$\begin{array}{l}\text { SWCG } \\
(n=683)\end{array}$} & BW (kg) & $53.23 \pm 0.73^{\mathrm{A}}(n=436)$ & $46.79 \pm 1.39^{\mathrm{B}}(n=120)$ & - & 0.0006 \\
\hline & $\mathrm{BH}(\mathrm{cm})$ & $57.01 \pm 0.20^{\mathrm{a}}(n=544)$ & $55.96 \pm 0.46^{\mathrm{B}}(n=136)$ & - & 0.022 \\
\hline & $\mathrm{BL}(\mathrm{cm})$ & $67.10 \pm 0.30^{\mathrm{b}}(n=392)$ & $66.54 \pm 0.53^{\mathrm{a}}(n=111)$ & - & 0.369 \\
\hline & $\mathrm{HAH}(\mathrm{cm})$ & $19.87 \pm 0.17(n=545)$ & $20.32 \pm 0.34(n=137)$ & - & 0.223 \\
\hline & $\mathrm{CC}(\mathrm{cm})$ & $59.83 \pm 0.18^{a}(n=542)$ & $58.69 \pm 0.49^{\mathrm{b}}(n=137)$ & - & 0.033 \\
\hline & $\mathrm{CD}(\mathrm{cm})$ & $15.45 \pm 0.12(n=285)$ & $15.45 \pm 0.21(n=95)$ & - & 0.982 \\
\hline & $\mathrm{CW}(\mathrm{cm})$ & $8.34 \pm 0.12(n=545)$ & $8.31 \pm 0.07(n=138)$ & - & 0.899 \\
\hline & $\mathrm{HW}(\mathrm{cm})$ & $85.08 \pm 0.36(n=544)$ & $83.87 \pm 0.74(n=138)$ & - & 0.135 \\
\hline & $\mathrm{CCB}(\mathrm{cm})$ & $29.20 \pm 0.13(n=544)$ & $29.2 \pm 0.23(n=137)$ & - & 0.862 \\
\hline \multirow{10}{*}{$\begin{array}{l}\text { HNBG } \\
(n=205)\end{array}$} & $\mathrm{BH}(\mathrm{cm})$ & $52.84 \pm 0.43(n=92)$ & $52.87 \pm 0.41(n=98)$ & $52.05 \pm 1.11(n=15)$ & 0.749 \\
\hline & $\mathrm{BL}(\mathrm{cm})$ & $55.96 \pm 0.44(n=92)$ & $56.51 \pm 0.48(n=98)$ & $55.05 \pm 1.10(n=15)$ & 0.383 \\
\hline & $\mathrm{CC}(\mathrm{cm})$ & $72.88 \pm 0.62(n=92)$ & $72.01 \pm 0.69(n=98)$ & $71.80 \pm 2.08(n=15)$ & 0.652 \\
\hline & $\mathrm{CD}(\mathrm{cm})$ & $26.71 \pm 0.21(n=92)$ & $26.37 \pm 0.25(n=98)$ & $26.85 \pm 0.16(n=15)$ & 0.567 \\
\hline & $\mathrm{CW}(\mathrm{cm})$ & $15.09 \pm 0.17(n=92)$ & $14.7 \pm 0.21(n=98)$ & $14.9 \pm 0.13(n=15)$ & 0.517 \\
\hline & $\mathrm{HW}(\mathrm{cm})$ & $13.78 \pm 0.14(n=92)$ & $13.69 \pm 0.13(n=98)$ & $13.5 \pm 0.46(n=15)$ & 0.670 \\
\hline & $\mathrm{CCB}(\mathrm{cm})$ & $7.82 \pm 0.74(n=92)$ & $7.76 \pm 0.73(n=97)$ & $7.90 \pm 0.24(n=15)$ & 0.722 \\
\hline & BI & $130.68 \pm 1.07^{\mathrm{a}}(n=92)$ & $127.52 \pm 0.71^{\mathrm{b}}(n=98)$ & $130.36 \pm 2.59^{\mathrm{a}}(n=15)$ & 0.044 \\
\hline & BLI & $106.22 \pm 0.84(n=92)$ & $107.09 \pm 0.77(n=98)$ & $106.19 \pm 0.55(n=15)$ & 0.687 \\
\hline & ChCI & $138.19 \pm 1.00(n=92)$ & $136.33 \pm 0.98(n=98)$ & $138.15 \pm 3.50(n=15)$ & 0.412 \\
\hline \multirow{6}{*}{$\begin{array}{l}\text { GZDG } \\
(n=80)\end{array}$} & $\mathrm{BH}(\mathrm{cm})$ & $73.35 \pm 0.51(n=75)$ & $76.2 \pm 1.07(n=5)$ & - & 0.147 \\
\hline & $\mathrm{BL}(\mathrm{cm})$ & $74.63 \pm 0.51(n=75)$ & $77.60 \pm 1.40(n=5)$ & - & 0.132 \\
\hline & $\mathrm{HAH}(\mathrm{cm})$ & $73.92 \pm 0.49(n=75)$ & $76.40 \pm 1.36(n=5)$ & - & 0.197 \\
\hline & HW (cm) & $16.65 \pm 0.10^{\mathrm{B}}(n=23)$ & $17.00 \pm 0.00^{\mathrm{A}}(n=3)$ & - & 0.002 \\
\hline & $\mathrm{CC}(\mathrm{cm})$ & $87.35 \pm 0.51(n=23)$ & $88.67 \pm 1.67(n=3)$ & - & 0.395 \\
\hline & $\mathrm{CCB}(\mathrm{cm})$ & $8.00 \pm 0.00(n=23)$ & $8.00 \pm 0.00(n=3)$ & - & 0.000 \\
\hline \multirow{9}{*}{$\begin{array}{l}\text { IMWC } \\
(n=68)\end{array}$} & $\mathrm{BW}(\mathrm{kg})$ & $34.30 \pm 1.06(n=47)$ & $36.74 \pm 1.66(n=21)$ & - & 0.211 \\
\hline & $\mathrm{BH}(\mathrm{cm})$ & $56.86 \pm 0.51(n=47)$ & $55.81 \pm 0.76(n=21)$ & - & 0.255 \\
\hline & $\mathrm{BL}(\mathrm{cm})$ & $66.67 \pm 0.62(n=47)$ & $66.40 \pm 0.80(n=21)$ & - & 0.805 \\
\hline & $\mathrm{HAH}(\mathrm{cm})$ & $59.86 \pm 0.56(n=47)$ & $60.35 \pm 0.77(n=21)$ & - & 0.615 \\
\hline & $\mathrm{CC}(\mathrm{cm})$ & $78.48 \pm 0.94(n=47)$ & $81.02 \pm 1.48(n=21)$ & - & 0.142 \\
\hline & $\mathrm{CD}(\mathrm{cm})$ & $29.52 \pm 0.33(n=47)$ & $20.40 \pm 0.44(n=21)$ & - & 0.841 \\
\hline & $\mathrm{CW}(\mathrm{cm})$ & $18.62 \pm 0.37(n=47)$ & $19.21 \pm 0.52(n=21)$ & - & 0.361 \\
\hline & $\mathrm{HW}(\mathrm{cm})$ & $15.97 \pm 0.83(n=47)$ & $15.36 \pm 0.23(n=21)$ & - & 0.611 \\
\hline & $\mathrm{CCB}(\mathrm{cm})$ & $8.38 \pm 0.68(n=47)$ & $8.57 \pm 0.11(n=21)$ & - & 0.140 \\
\hline
\end{tabular}

Body weight, BW; body height, $\mathrm{BH}$; body length, BL; chest width, $\mathrm{CW}$; chest depth, $\mathrm{CD}$; chest circumference, $\mathrm{CC}$; height across the hip, $\mathrm{HAH}$; rump length, RL; hip width, HW; circumference of cannon bone, CCB; body index, BI; body length index, BLI; chest circumference index, $\mathrm{ChCI}$. The traits that have a significant association between genotype and phenotype are bold $\left({ }^{\mathrm{A}, \mathrm{B}} p<0.01{ }^{\text {a, }}: p<0.05\right)$. 
Table 5. Association of the 15-bp InDel and growth traits in lambs of SWCG and IMWC goat breeds (mean \pm SE).

\begin{tabular}{|c|c|c|c|c|c|}
\hline \multirow{2}{*}{ Breeds } & \multirow{2}{*}{ Growth Traits } & \multicolumn{3}{|c|}{ Genotypes } & \multirow{2}{*}{$p$ Value } \\
\hline & & II & ID & DD & \\
\hline \multirow{9}{*}{$\begin{array}{l}\text { SWCG } \\
(n=89)\end{array}$} & BW (kg) & $35.67 \pm 0.90(n=73)$ & $32.91 \pm 1.74(n=16)$ & - & 0.187 \\
\hline & $\mathrm{BH}(\mathrm{cm})$ & $49.99 \pm 0.44(n=73)$ & $48.89 \pm 1.10(n=16)$ & - & 0.305 \\
\hline & $\mathrm{BL}(\mathrm{cm})$ & $62.90 \pm 0.62(n=73)$ & $62.29 \pm 1.47(n=16)$ & - & 0.681 \\
\hline & HAH (cm) & $54.03 \pm 0.50^{\mathrm{a}}(n=73)$ & $51.46 \pm 1.26^{\mathrm{b}}(n=16)$ & - & 0.036 \\
\hline & $\mathrm{CC}(\mathrm{cm})$ & $79.85 \pm 0.84(n=73)$ & $76.81 \pm 1.85(n=16)$ & - & 0.130 \\
\hline & $\mathrm{CD}(\mathrm{cm})$ & $28.19 \pm 0.29(n=73)$ & $27.45 \pm 1.05(n=16)$ & - & 0.345 \\
\hline & $\mathrm{CW}(\mathrm{cm})$ & $20.57 \pm 0.32(n=73)$ & $20.17 \pm 0.75(n=16)$ & - & 0.602 \\
\hline & $\mathrm{HW}(\mathrm{cm})$ & $15.20 \pm 0.20(n=73)$ & $14.88 \pm 1.69(n=16)$ & - & 0.493 \\
\hline & $\mathrm{CCB}(\mathrm{cm})$ & $8.01 \pm 0.10(n=73)$ & $7.62 \pm 0.24(n=16)$ & - & 0.122 \\
\hline \multirow{9}{*}{$\begin{array}{c}\text { IMWC } \\
(n=373)\end{array}$} & BW (kg) & $21.79 \pm 0.34(n=267)$ & $22.94 \pm 0.59(n=106)$ & - & 0.076 \\
\hline & $\mathrm{BH}(\mathrm{cm})$ & $50.69 \pm 0.23(n=265)$ & $50.18 \pm 0.40(n=106)$ & - & 0.245 \\
\hline & $\mathrm{BL}(\mathrm{cm})$ & $54.56 \pm 0.33(n=266)$ & $55.18 \pm 0.49(n=106)$ & - & 0.304 \\
\hline & $\mathrm{HAH}(\mathrm{cm})$ & $52.19 \pm 0.24(n=265)$ & $52.01 \pm 0.40(n=106)$ & - & 0.692 \\
\hline & $\mathrm{CC}(\mathrm{cm})$ & $67.46 \pm 0.39(n=265)$ & $68.71 \pm 0.63(n=106)$ & - & 0.089 \\
\hline & $\mathrm{CD}(\mathrm{cm})$ & $23.30 \pm 0.17(n=266)$ & $23.37 \pm 0.25(n=106)$ & - & 0.828 \\
\hline & $\mathrm{CW}(\mathrm{cm})$ & $13.90 \pm 0.13(n=266)$ & $14.30 \pm 0.21(n=106)$ & - & 0.105 \\
\hline & HW (cm) & $12.34 \pm 0.10^{\mathrm{B}}(n=266)$ & $12.86 \pm 0.15^{\mathrm{A}}(n=105)$ & - & 0.005 \\
\hline & $\mathrm{CCB}(\mathrm{cm})$ & $8.43 \pm 0.03(n=265)$ & $8.42 \pm 0.06(n=106)$ & - & 0.977 \\
\hline
\end{tabular}

Note: body height, $\mathrm{BH}$; body length, BL; chest width, CW; chest depth, CD; chest circumference, CC; height across the hip, HAH; rump length, RL; hip width, HW; circumference of cannon bone, CCB; BLI, body length index; ChCI, chest circumference index. The traits that have a significant association between genotype and phenotype are bold $\left({ }^{\mathrm{A}, \mathrm{B}} p<0.01\right.$; $\left.{ }^{\mathrm{a}, \mathrm{b}} p<0.05\right)$.

\section{Discussion}

Genetic resources serve as strategic resources in agricultural production. In previous studies, gene variations have been shown to be associated with the growth-related traits of goats [28,37-39]. In goat breeding and husbandry, growth traits play a vital role in a variety of economic characteristics, such as meat and fur production; hence, exploring candidate molecular makers for goat breeding is important. In this study, PLAG1 was identified as a candidate gene affecting goat growth traits, and the relationship between the $15 \mathrm{bp}$ InDel (rs637141549) and the growth traits of a different breed of goat was observed. The analysis of genetic parameters showed that the $15 \mathrm{bp} \mathrm{InDel} \mathrm{was} \mathrm{not} \mathrm{at} \mathrm{Hardy-Weinberg} \mathrm{equilibrium}$ state in the four breeds, which may have been due to artificial selection, genetic drift and migration causing mutations in the locus [40]. Additionally, the allele frequency of "I" was noted to be higher than that of " $\mathrm{D}$ " in all goat breeds. Compared to the DD genotype, II was the dominant genotype in SWCG and had a distinctly better phenotype, while the phenotypes of GZDG and IMWC were in reverse. Here, rs637141549 (15 bp InDel) of PLAG1 was found to be significantly correlated with body weight $(p=0.0006)$, body height $(p=0.022)$, chest circumference $(p=0.033)$, hip width $(p=0.002)$ and body index $(p=0.044)$ of adults in different goat breeds. In lambs, significant correlations were present between this variation with growth traits, including height at hip cross $(p=0.036)$ and hip width $(p=0.005)$. Evidently, the phenotypes of each breed were positively correlated. Hence, it was further speculated that rs637141549 (15 bp InDel) may also affect other growth-related phenotypes of goat breeds.

PLAG1 is a millennia-old derived allele, which has an important effect on body weight and body size [41]. As a transcription factor, the N-terminus of PLAG1 contains seven canonical $\mathrm{C} 2 \mathrm{H} 2$ zinc finger domains responsible for the DNA-binding ability of proteins, while the $\mathrm{C}$-terminus contains a serine-rich region that has transcriptional activation activity. At the same time, it can be used as a nucleoprotein and participates in the docking between protein and nuclear pores through the N-terminal zinc finger region as well as the nucleoprotein $\mathrm{A} 2$ recognition site [12]. However, evidence pertaining to an important role of PLAG1 in mammalian growth has been increasing, though its specific mechanism requires further elucidation. For example, it is clear that PLAG1 highly upregulated the 
expression levels of Insulin-like growth factor 2 (IGF2) and other important growth factors. IGF2 plays an essential role in bone growth and development, myogenesis, vasculogenesis, and cardiac development [42-44]. Moreover, PLAG1 could bind the IGF2 promoter and stimulate its activity, illustrating that PLAG1 plays an indispensable role in promoting its transcriptional expression [45]. In addition, Van Laere et al. identified a mutation located in QTL of the IGF2 gene that affects pig muscle growth (IGF2-intron3-G3072A), indicating that regulatory mutation has an important role in controlling phenotypic variation. This was a typical example of non-coding region variation that may influence transcription efficiency and mRNA stability [46-49].

Simultaneously, PLAG1 has been found to induce the upregulation of several genes associated with Wnt signaling, which are essential for the growth and development of mice [50]. Moreover, studies have found that the CHCHD7 gene shares a bidirectional promoter with PLAG1, which is only 440-bp away from PLAG1. As a fusion partner of PLAG1, CHCHD7 mutation has recently been shown to regulate the growth traits of goats [51]. Similarly, as the upstream activator of PLAG1, HMGA2 can also affect the body height of adults and lambs. Accordingly, it is speculated that these results may relate to PLAG1, resulting in the regulation of body height and growth traits [52]. This was consistent with the result in which PLAG1 knockout mice showed dwarfism without other symptoms, while cattle with PLAG1 gene overexpression increased in withers height. In addition, PLAG1 expression was different in early life and adulthood [22,53]. These results were identified between this mutation and the growth traits among the four goat breeds at different growth stages in order to ensure accurate and reliable results. The results obtained in this study shows that PLAG1 mutation has similar effects on growth and development in goats as in other mammals. Briefly, the 15-bp InDel mutation of PLAG1 is of great value in the genetic selection of growth traits in goats and may serve as an effective molecular marker in selection of goats with better growth performance. PLAG1 may be one of the most promising candidate genes for the breeding of goats, and the regulatory mutations within PLAG1 are important for selecting the corresponding phenotypic traits [54,55].

\section{Conclusions}

The 15-bp deletion mutation of PLAG1 was detected in large samples among four native superior goat breeds. The results demonstrated that it can significantly improve growth traits, such as stature and weight. These results indicate that 15-bp InDel variation of PLAG1 is of great value in the genetic selection of growth traits in goats and may serve as a useful DNA marker for selecting excellent goat individuals.

Author Contributions: Data collection, Z.W. (Zhenyu Wei), K.W., H.W., Z.W. (Zhen Wang); Methodology, Z.W. (Zhenyu Wei), K.W.; Software, H.W.; Conducting experiment, Z.W. (Zhenyu Wei); Writing—original draft, Z.W. (Zhenyu Wei); Writing—review \& editing, Z.W. (Zhenyu Wei), X.L.; Project administration, C.P., H.C., X.L.; Funding acquisition, C.P., H.C., X.L. All authors have read and agreed to the published version of the manuscript.

Funding: This research was funded by the National Natural Science Foundation of China (No. 32060734; 31172184).

Institutional Review Board Statement: All animal studies were conducted in accordance with an animal use protocol approved by the Institutional Animal Care and Use Committee of the Northwest A\&F University (Protocol No. NWAFU-314020038). All the experimental contents in this study are in full compliance with local animal welfare guidelines, laws and policies.

Data Availability Statement: Data is contained within the article.

Acknowledgments: We are very grateful to Lei Qu and his team from Shaanxi Province Engineering \& Technology Research Center of Cashmere Goats (Shaanxi, China) as well as Yulin University for their support in our test samples and data. We are also very grateful to the Life Science Research Core Service (LSRCS) of Northwest Agriculture and Forestry University (North Campus) for providing us with the platform. 
Conflicts of Interest: We confirm that the materials discussed in the manuscript have no conflicts of interest with any financial organization, and the publication of the manuscript has been approved by all authors.

\section{References}

1. Guan, D.L.; Luo, N.J.; Tan, X.S.; Zhao, Z.Q.; Huang, Y.F.; Na, R.S.; Zhang, J.H.; Zhao, Y.J. Scanning of selection signature provides a glimpse into important economic traits in goats (Capra hircus). Sci. Rep. 2016, 6. [CrossRef]

2. Wang, K.; Yan, H.L.; Xu, H.; Yang, Q.; Zhang, S.H.; Pan, C.Y.; Chen, H.; Zhu, H.J.; Liu, J.W.; Qu, L.; et al. A novel indel within goat casein alpha S1 gene is significantly associated with litter size. Gene 2018, 671, 161-169. [CrossRef]

3. Dai, B.; Liang, H.; Guo, D.D.; Bi, Z.W.; Yuan, J.L.; Jin, Y.; Huan, L.; Guo, X.D.; Cang, M.; Liu, D.J. The Overexpression of T $\beta 4$ in the Hair Follicle Tissue of Alpas Cashmere Goats Increases Cashmere Yield and Promotes Hair Follicle Development. Animals 2019, 10, 75. [CrossRef]

4. Shaat, I.; Maki-Tanila, A. Variation in direct and maternal genetic effects for meat production traits in Egyptian Zaraibi goats. J. Anim. Breed. Genet. 2009, 126, 198-208. [CrossRef] [PubMed]

5. Collard, B.C.; Mackill, D.J. Marker-assisted selection: An approach for precision plant breeding in the twenty-first century. Philos. Trans. R. Soc. Lond. B. Biol. Sci. 2008, 363, 557-572. [CrossRef]

6. Wang, Z.; Zhang, X.; Jiang, E.; Yan, H.; Zhu, H.; Chen, H.; Liu, J.; Qu, L.; Pan, C.; Lan, X. InDels within caprine IGF2BP1 intron 2 and the $3^{\prime}$-untranslated regions are associated with goat growth traits. Anim. Genet. 2020, 51, 117-121. [CrossRef] [PubMed]

7. Wang, K.; Cui, Y.; Wang, Z.; Yan, H.L.; Meng, Z.; Zhu, H.J.; Qu, L.; Lan, X.Y.; Pan, C.Y. One 16 bp insertion/deletion (indel) within the KDM6A gene revealing strong associations with growth traits in goat. Gene 2019, 686, 16-20. [CrossRef] [PubMed]

8. Li, W.Y.; Liu, D.L.; Tang, S.Q.; Li, D.H.; Han, R.L.; Tian, Y.D.; Li, H.; Li, G.X.; Li, W.T.; Liu, X.J.; et al. A multiallelic indel in the promoter region of the Cyclin-dependent kinase inhibitor 3 gene is significantly associated with body weight and carcass traits in chickens. Poult. Sci. 2019, 98, 556-565. [CrossRef]

9. Ren, T.; Li, W.; Liu, D.; Liang, K.; Wang, X.; Li, H.; Jiang, R.; Tian, Y.; Kang, X.; Li, Z. Two insertion/deletion variants in the promoter region of the QPCTL gene are significantly associated with body weight and carcass traits in chickens. Anim. Genet. 2019, 50, 279-282. [CrossRef]

10. Wang, J.; Zhou, H.; Luo, Y.; Zhao, M.; Gong, H.; Hao, Z.; Hu, J.; Hickford, J.G.H. Variation in the Caprine KAP24-1 Gene Affects Cashmere Fibre Diameter. Animals 2019, 9, 15. [CrossRef]

11. Kas, K.; Voz, M.L.; Röijer, E.; Aström, A.K.; Meyen, E.; Stenman, G.; Van de Ven, W.J. Promoter swapping between the genes for a novel zinc finger protein and beta-catenin in pleiomorphic adenomas with $\mathrm{t}(3 ; 8)(\mathrm{p} 21 ; \mathrm{q} 12)$ translocations. Nat. Genet. 1997, 15, 170-174. [CrossRef]

12. Van Dyck, F.; Declercq, J.; Braem, C.V.; Van de Ven, W.J. PLAG1, the prototype of the PLAG gene family: Versatility in tumour development (review). Int. J. Oncol. 2007, 30, 765-774. [CrossRef]

13. Cho, Y.S.; Go, M.J.; Kim, Y.J.; Heo, J.Y.; Oh, J.H.; Ban, H.J.; Yoon, D.; Lee, M.H.; Kim, D.J.; Park, M.; et al. A large-scale genome-wide association study of Asian populations uncovers genetic factors influencing eight quantitative traits. Nat. Genet. 2009, 41, 527-534. [CrossRef]

14. Kim, J.J.; Lee, H.I.; Park, T.; Kim, K.; Lee, J.E.; Cho, N.H.; Shin, C.; Cho, Y.S.; Lee, J.Y.; Han, B.G.; et al. Identification of 15 loci influencing height in a Korean population. J. Hum. Genet. 2010, 55, 27-31. [CrossRef]

15. Okada, Y.; Kamatani, Y.; Takahashi, A.; Matsuda, K.; Hosono, N.; Ohmiya, H.; Daigo, Y.; Yamamoto, K.; Kubo, M.; Nakamura, Y.; et al. A genome-wide association study in 19633 Japanese subjects identified LHX3-QSOX2 and IGF1 as adult height loci. Hum. Mol. Genet. 2010, 19, 2303-2312. [CrossRef] [PubMed]

16. Gudbjartsson, D.F.; Walters, G.B.; Thorleifsson, G.; Stefansson, H.; Halldorsson, B.V.; Zusmanovich, P.; Sulem, P.; Thorlacius, S.; Gylfason, A.; Steinberg, S.; et al. Many sequence variants affecting diversity of adult human height. Nat. Genet. 2008, 40, 609-615. [CrossRef] [PubMed]

17. Lettre, G.; Jackson, A.U.; Gieger, C.; Schumacher, F.R.; Berndt, S.I.; Sanna, S.; Eyheramendy, S.; Voight, B.F.; Butler, J.L.; Guiducci, C.; et al. Identification of ten loci associated with height highlights new biological pathways in human growth. Nat. Genet. 2008, 40, 584-591. [CrossRef] [PubMed]

18. Lango Allen, H.; Estrada, K.; Lettre, G.; Berndt, S.I.; Weedon, M.N.; Rivadeneira, F.; Willer, C.J.; Jackson, A.U.; Vedantam, S.; Raychaudhuri, S.; et al. Hundreds of variants clustered in genomic loci and biological pathways affect human height. Nature 2010, 467, 832-838. [CrossRef] [PubMed]

19. Wood, A.R.; Esko, T.; Yang, J.; Vedantam, S.; Pers, T.H.; Gustafsson, S.; Chun, A.Y.; Estrada, K.; Luan, J.; Kutalik, Z.; et al. Defining the role of common variation in the genomic and biological architecture of adult human height. Nat. Genet. 2014, 46, 1173-1186. [CrossRef]

20. Hensen, K.; Braem, C.; Declercq, J.; Van Dyck, F.; Dewerchin, M.; Fiette, L.; Denef, C.; Van de Ven, W.J. Targeted disruption of the murine PLAG1 proto-oncogene causes growth retardation and reduced fertility. Dev. Growth. Differ. 2004, 46, 459-470. [CrossRef] [PubMed]

21. Saatchi, M.; Schnabel, R.D.; Taylor, J.F.; Garrick, D.J. Large-effect pleiotropic or closely linked QTL segregate within and across ten US cattle breeds. BMC Genom. 2014, 15, 442. [CrossRef] [PubMed] 
22. Littlejohn, M.; Grala, T.; Sanders, K.; Walker, C.; Waghorn, G.; Macdonald, K.; Coppieters, W.; Georges, M.; Spelman, R.; Hillerton, E.; et al. Genetic variation in PLAG1 associates with early life body weight and peripubertal weight and growth in Bos taurus. Anim. Genet. 2012, 43, 591-594. [CrossRef] [PubMed]

23. Fortes, M.R.; Kemper, K.; Sasazaki, S.; Reverter, A.; Pryce, J.E.; Barendse, W.; Bunch, R.; McCulloch, R.; Harrison, B.; Bolormaa, S.; et al. Evidence for pleiotropism and recent selection in the PLAG1 region in Australian Beef cattle. Anim. Genet. 2013, 44, 636-647. [CrossRef] [PubMed]

24. Bouwman, A.C.; Daetwyler, H.D.; Chamberlain, A.J.; Ponce, C.H.; Sargolzaei, M.; Schenkel, F.S.; Sahana, G.; Govignon-Gion, A.; Boitard, S.; Dolezal, M.; et al. Meta-analysis of genome-wide association studies for cattle stature identifies common genes that regulate body size in mammals. Nat. Genet. 2018, 50, 362. [CrossRef] [PubMed]

25. Rubin, C.J.; Megens, H.J.; Martinez Barrio, A.; Maqbool, K.; Sayyab, S.; Schwochow, D.; Wang, C.; Carlborg, O.; Jern, P.; Jorgensen, C.B.; et al. Strong signatures of selection in the domestic pig genome. Proc. Natl. Acad. Sci. USA 2012, 109, 19529-19536. [CrossRef]

26. Guo, Y.; Hou, L.; Zhang, X.; Huang, M.; Mao, H.; Chen, H.; Ma, J.; Chen, C.; Ai, H.; Ren, J.; et al. A meta analysis of genome-wide association studies for limb bone lengths in four pig populations. BMC Genet. 2015, 16, 95. [CrossRef]

27. Metzger, J.; Philipp, U.; Lopes, M.S.; Machado, A.D.; Felicetti, M.; Silvestrelli, M.; Distl, O. Analysis of copy number variants by three detection algorithms and their association with body size in horses. BMC Genom. 2013, 14. [CrossRef]

28. Wu, H.; Pan, Y.; Zhang, Q.F.; Cao, Y.; Li, J.; Chen, H.; Cai, Y.; Sun, X.Z.; Lan, X.Y. Insertion/deletion (InDel) variations in sheep PLAG1 gene locating in growth-related major QTL are associated with adult body weight and morphometric traits. Small Rumin. Res. 2019, 178, 63-69. [CrossRef]

29. Pan, Y.; Wang, M.; Wu, H.; Akhatayeva, Z.; Lan, X.Y.; Fei, P.F.; Mao, C.; Jiang, F.G. Indel mutations of sheep PLAG1 gene and their associations with growth traits. Anim. Biotechnol. 2021. [CrossRef]

30. Zhang, X.; Wu, X.; Jia, W.; Pan, C.; Li, X.; Lei, C.; Chen, H.; Lan, X. Novel Nucleotide Variations, Haplotypes Structure and Associations with Growth Related Traits of Goat AT Motif-Binding Factor (ATBF1) Gene. Asian Australas. J. Anim. Sci. 2015, 28, 1394-1406. [CrossRef]

31. Aljanabi, S.M.; Martinez, I. Universal and rapid salt-extraction of high quality genomic DNA for PCR-based techniques. Nucleic Acids Res. 1997, 25, 4692-4693. [CrossRef] [PubMed]

32. Chen, M.; Wang, J.; Liu, N.; Cui, W.; Dong, W.; Xing, B.; Pan, C. Pig SOX9: Expression profiles of Sertoli cell (SCs) and a functional $18 \mathrm{bp}$ indel affecting testis weight. Theriogenology 2019, 138, 94-101. [CrossRef] [PubMed]

33. Li, J.; Zhu, X.; Ma, L.; Xu, H.; Cao, X.; Luo, R.; Chen, H.; Sun, X.; Cai, Y.; Lan, X. Detection of a new 20-bp insertion/deletion (indel) within sheep PRND gene using mathematical expectation (ME) method. Prion 2017, 11, 143-150. [CrossRef]

34. Botstein, D.; White, R.L.; Skolnick, M.; Davis, R.W. Construction of a genetic linkage map in man using restriction fragment length polymorphisms. Am. J. Hum. Genet. 1980, 32, 314-331. [PubMed]

35. Shi, Y.Y.; He, L. SHEsis, a powerful software platform for analyses of linkage disequilibrium, haplotype construction, and genetic association at polymorphism loci. Cell Res. 2005, 15, 97-98. [CrossRef] [PubMed]

36. Nei, M.; Roychoudhury, A.K. Sampling variances of heterozygosity and genetic distance. Genetics 1974, 76, 379-390. [CrossRef] [PubMed]

37. Wang, X.; Yang, Q.; Wang, K.; Zhang, S.; Pan, C.; Chen, H.; Qu, L.; Yan, H.; Lan, X. A novel 12-bp indel polymorphism within the GDF9 gene is significantly associated with litter size and growth traits in goats. Anim. Genet. 2017, 48, 735-736. [CrossRef] [PubMed]

38. Yang, Q.; Yan, H.; Li, J.; Xu, H.; Wang, K.; Zhu, H.; Chen, H.; Qu, L.; Lan, X. A novel 14-bp duplicated deletion within goat GHR gene is significantly associated with growth traits and litter size. Anim. Genet. 2017, 48, 499-500. [CrossRef] [PubMed]

39. Zhang, Y.H.; Wang, K.; Liu, J.W.; Zhu, H.J.; Qu, L.; Chen, H.; Lan, X.Y.; Pan, C.Y.; Song, X.Y. An 11-bp Indel Polymorphism within the CSN1S1 Gene Is Associated with Milk Performance and Body Measurement Traits in Chinese Goats. Animals 2019, 9, 1114. [CrossRef]

40. Bi, Y.; Feng, B.; Wang, Z.; Zhu, H.; Qu, L.; Lan, X.; Pan, C.; Song, X. Myostatin (MSTN) Gene Indel Variation and Its Associations with Body Traits in Shaanbei White Cashmere Goat. Animals 2020, 10, 168. [CrossRef]

41. Gao, J.; Song, X.; Wu, H.; Tang, Q.; Wei, Z.; Wang, X.; Lan, X.; Zhang, B. Detection of rs665862918 (15-bp Indel) of the HIAT1 Gene and its Strong Genetic Effects on Growth Traits in Goats. Animals 2020, 10, 358. [CrossRef]

42. Wang, X.; Yang, Q.; Wang, K.; Yan, H.; Pan, C.; Chen, H.; Liu, J.; Zhu, H.; Qu, L.; Lan, X. Two strongly linked single nucleotide polymorphisms (Q320P and V397I) in GDF9 gene are associated with litter size in cashmere goats. Theriogenology 2019, 125, 115-121. [CrossRef] [PubMed]

43. Utsunomiya, Y.T.; Milanesi, M.; Utsunomiya, A.T.H.; Torrecilha, R.B.P.; Kim, E.S.; Costa, M.S.; Aguiar, T.S.; Schroeder, S.; do Carmo, A.S.; Carvalheiro, R.; et al. A PLAG1 mutation contributed to stature recovery in modern cattle. Sci. Rep. 2017, 7, 17140. [CrossRef]

44. Minuto, F.; Palermo, C.; Arvigo, M.; Barreca, A.M. The IGF system and bone. J. Endocrinol. Investig. 2005, $28,8-10$.

45. Wilson, E.M.; Rotwein, P. Control of MyoD function during initiation of muscle differentiation by an autocrine signaling pathway activated by insulin-like growth factor-II. J. Biol. Chem. 2006, 281, 29962-29971. [CrossRef] [PubMed]

46. Harris, L.K.; Westwood, M. Biology and significance of signalling pathways activated by IGF-II. Growth Factors 2012, 30 , 1-12. [CrossRef] [PubMed] 
47. Voz, M.L.; Agten, N.S.; Van de Ven, W.J.; Kas, K. PLAG1, the main translocation target in pleomorphic adenoma of the salivary glands, is a positive regulator of IGF-II. Cancer Res. 2000, 60, 106-113. [PubMed]

48. Van Laere, A.S.; Nguyen, M.; Braunschweig, M.; Nezer, C.; Collette, C.; Moreau, L.; Archibald, A.L.; Haley, C.S.; Buys, N.; Tally, M.; et al. A regulatory mutation in IGF2 causes a major QTL effect on muscle growth in the pig. Nature 2003, 425, 832-836. [CrossRef]

49. Guan, B.; Gao, M.; Wu, C.H.; Wang, T.L.; Shih, I.M. Functional Analysis of In-frame Indel ARID1A Mutations Reveals New Regulatory Mechanisms of Its Tumor Suppressor Functions. Neoplasia 2012, 14, 986-993. [CrossRef]

50. Minor, E.A.; Court, B.L.; Dubovy, S.; Wang, G.F. AMD-Associated Variants at the Chromosome 10q26 Locus and the Stability of ARMS2 Transcripts. Investig. Ophth. Vis. Sci. 2013, 54, 5913-5919. [CrossRef] [PubMed]

51. Hou, J.; An, X.; Song, Y.; Gao, T.; Lei, Y.; Cao, B. Two Mutations in the Caprine MTHFR 3'UTR Regulated by MicroRNAs Are Associated with Milk Production Traits. PLoS ONE 2015, 10, e0133015. [CrossRef] [PubMed]

52. Declercq, J.; Van Dyck, F.; Van Damme, B.; Van de Ven, W.J. Upregulation of Igf and Wnt signalling associated genes in pleomorphic adenomas of the salivary glands in PLAG1 transgenic mice. Int. J. Oncol. 2008, 32, 1041-1047. [CrossRef] [PubMed]

53. Xu, H.; Li, H.; Wang, Z.; Abudureyimu, A.; Yang, J.; Cao, X.; Lan, X.; Zang, R.; Cai, Y. A Deletion Downstream of the CHCHD7 Gene Is Associated with Growth Traits in Sheep. Animals 2020, 10, 1472. [CrossRef]

54. Li, H.; Wang, X.; Chen, H.; Qu, L.; Lan, X. A 17-bp InDel (rs668420586) within goat CHCHD7 gene located in growth-related QTL affecting body measurement traits. 3 Biotech 2020, 10, 441. [CrossRef] [PubMed]

55. Karim, L.; Takeda, H.; Lin, L.; Druet, T.; Arias, J.A.; Baurain, D.; Cambisano, N.; Davis, S.R.; Farnir, F.; Grisart, B.; et al. Variants modulating the expression of a chromosome domain encompassing PLAG1 influence bovine stature. Nat. Genet. 2011, 43, 405-413. [CrossRef] [PubMed] 